\title{
Microplastics in commercial bivalves harvested from intertidal seagrasses and sandbanks in the Ria Formosa lagoon, Portugal
}

Lorenzo Cozzolino ${ }^{a}$, Carmen B. de los Santos ${ }^{a}$, Gerardo I. Zardi ${ }^{\mathrm{b}}$, Katy R. Nicastro ${ }^{\mathrm{a}, \mathrm{b},{ }^{*}}$

${ }^{a}$ CCMAR - Centre of Marine Sciences of Algarve, University of Algarve, Campus de Gambelas, 8005-139, Faro, Portugal.

${ }^{b}$ Department of Zoology and Entomology, Rhodes University, 6140 Grahamstown, South Africa.

* corresponding author. Email address: katynicastro@gmailcom

https://doi.org/10.1071/MF20202

Received 27 June 2020, accepted 11 January 2021, published online 19 February 2021. 


\begin{abstract}
Through seafood consumption, microplastic (MP) pollution is potentially threatening human health. Commercial bivalves in particular are a cause of major concern because their filter-feeding activity directly exposes them to MP in the water column and they are then ingested by humans. Here, we provide a quantitative and qualitative baseline data on MP content in the soft tissues of three commercially important bivalves (Ruditapes decussatus, Cerastoderma spp. and Polititapes spp.) collected in Ria Formosa lagoon, southern Portugal. The abundance of MPs (items per soft tissue weight) did not significantly differ among species. On average, $R$. decussatus exhibited the highest MP abundance (on average, 18.4 \pm 21.9 MP items g-1 WW), followed by Cerastoderma spp. (11.9 $\pm 5.5 \mathrm{MP}$ items g-1 WW) and Polititapes spp. (10.4 $\pm 10.4 \mathrm{MP}$ items g-1 WW). Overall, $88 \%$ of the MPs found were synthetic fibres, the majority of which were blue (52\%). Size categories $>0.1-1 \mathrm{~mm}$ and $>1-5 \mathrm{~mm}$ were the most common ( $60 \%$ and $34 \%$ respectively). The most represented polymers were polyethylene (PE) and polystyrene (PS). The unexpectedly high number of MPs recorded in the three commercially exploited species suggests that this semi-closed lagoon system is experiencing a higher anthropogenic pressure than are open coastal systems.
\end{abstract}

\title{
Keywords
}

Cerastoderma spp., FTIR, marine debris, microfibers, Polititapes spp., Ruditapes decussatus, seafood. 


\section{Introduction}

Microplastic (MP) pollution poses severe threats to marine biodiversity (Barnes et al. 2009; Alomar et al. 2016) and it may eventually affect human health through seafood consumption (Smith et al. 2018). Bivalves are of particular concern because, as filter feeders, they are directly exposed to natural and anthropogenically derived microparticles in the water column (Ward et al. 2019a). Despite bivalves being able to select food particles at pre- and post- ingestion levels according to particle size, shape and surface characteristics (Ward et al. 2019b), the eventual assimilation of non-natural particulate matter can cause physical damage to the digestive organs (von Moos et al. 2012). Other consequences include neurotoxicity and adverse effects on the immune and reproductive systems (Avio et al. 2015; Sussarellu et al. 2016; Ribeiro et al. 2017; Tallec et al. 2018), possibly linked to the leaching of plastic chemicals (i.e. bisphenol A, phthalates, polychlorinated biphenyls; Browne et al. 2008). In addition to ingestion, recent research highlighted a novel pathway of MP uptake through adhesion or direct contact with the soft tissues of the blue mussel Mytilus edulis (Kolandhasamy et al. 2018). Regardless of the uptake mechanism, the presence of MP has been reported in wild, farmed and sold bivalves worldwide, such as the mussels Mytilus edulis and M. galloprovincialis, and the oysters Crassostrea gigas and C. angulata (De Witte et al. 2014; Van Cauwenberghe and Janssen 2014; Rochman et al. 2015; Li et al. 2015, 2018; Karlsson et al. 2017; Catarino et al. 2018; Digka et al. 2018; Murphy 2018). Other than for humans, bivalves are a food source for many marine organisms such as gastropods, crustaceans, fishes and marine birds (Dame 2016) and their contamination could affect higher trophic levels and lead to bioaccumulation through the food web (Farrell and Nelson 2013).

This study aims to provide a baseline assessment of MP abundance and type (visual and spectroscopic) in three commercially valuable bivalve species harvested from intertidal areas of Ria Formosa coastal lagoon (southern Portugal). This lagoon was declared a Natural Park in 1987, recognising it as an important natural wetland with high social, cultural and economic value (Aníbal et al. 2019). It comprises a complex network of channels and tidal flats dominated by coastal vegetation. Specifically, the back-barrier mudflats are largely colonised by the intertidal seagrass Zostera noltei and subtidal seagrasses Cymodocea nodosa and Zostera marina (Cunha et al. 2009). The intertidal seagrasses cover ,2900 ha of the total intertidal area (Guimarães et al. 2012), providing important ecological functions and ecosystem services, in particular, feeding, breeding and nursery habitats, eventually supporting local fisheries (Ribeiro et al. 2006; Guimarães et al. 2012). Bivalve exploitation is one of the most important economic activities in Ria Formosa (Bernardino 2000; 
Guimarães et al. 2012; Oliveira et al. 2013). About 395 ha of the intertidal area is occupied by clam or oyster farms (Guimarães et al. 2012; Oliveira et al. 2013), and 10 000 ha are dedicated to manual harvesting of wild clams and cockles (Bernardino 2000). However, despite the recent implementation of wastewater treatment plant sites (WWTPs) to reduce the deterioration of the water quality (Almeida and Soares 2012), bivalves growing in the intertidal areas of Ria Formosa are exposed to pollutants from untreated sewage, industrial discharges, and agriculture and storm-water runoff (Bebianno 1995; Veloso et al. 2015).

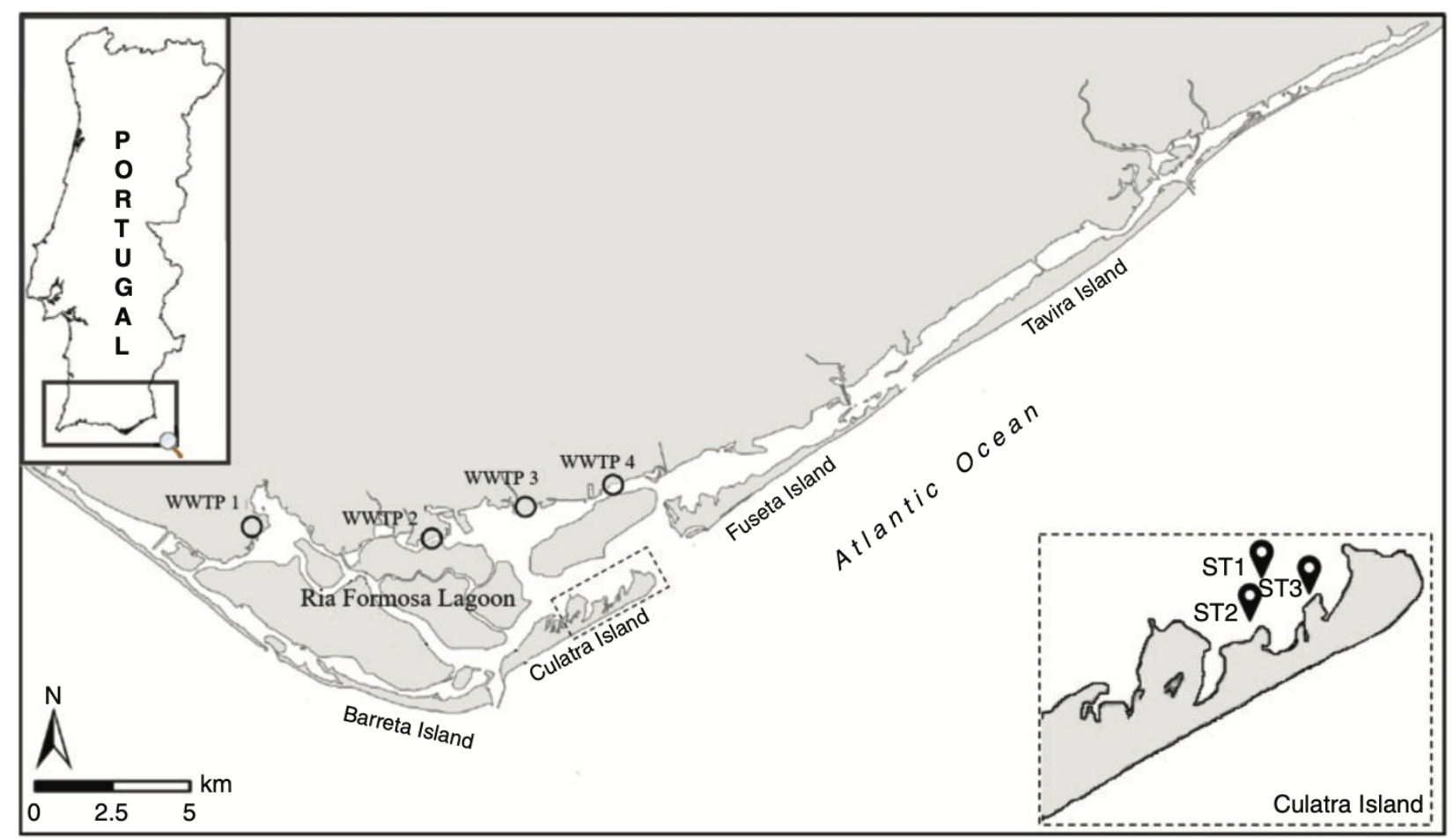

Fig. 1. Location of the three sampling stations (ST1, ST2 and ST3) in Culatra Island (Ria Formosa, Portugal) and the four wastewater treatment plants (WWTP1, WWTP2, WWTP3 and WWTP4) in the western sector. The average annual volume of wastewater treated is more than $\mathrm{hm}^{3}$ in the period between 2010 and 2018 (source: https://www.aguasdoalgarve.pt/).

\section{Materials and methods}

\subsection{Sample collection}

The study was conducted in the Ria Formosa, a sheltered large mesotidal lagoon located in the Algarve, southern Portugal (Fig. 1). Three stations (ST1 36.9965378-7.8307958, ST2 36.99603487.8287888, and ST3 36.9990098-7.8282948), consisting of paired habitats of intertidal Zostera noltei 
seagrass meadows and sandbanks, were sampled during low tide between April 2017 and January 2018 in Culatra island (Fig. 1), an area where bivalves are manually harvested by locals. Polititapes spp. (golden carpet shell) was found within Z. noltei meadows, whereas Cerastoderma spp. (edible cockle) and $R$. decussatus (grooved carpet shell) were associated with sandbanks. In each habitat, sediment cores $(n=5)$ were taken using a PVC corer (diameter $15.6 \mathrm{~cm}$ ) at a depth of $20 \mathrm{~cm}$. Each core content was sieved in situ and cleaned of sediment by using 1-mm black mesh and transported to the laboratory under dark cool conditions $(<3 \mathrm{~h})$. In the laboratory, samples were inspected and only individuals confirmed to be alive of the three species of bivalves were transferred to individual flasks and kept in $-20^{\circ} \mathrm{C}$ with their shells, to preserve the soft tissue from external contamination. Bivalves were not subjected to depuration period before analysis because we wanted to measure the absolute MP abundance, including those particles recently ingested or potentially translocated to the tissues (Li et al. 2015).

\subsection{Microplastic quantification}

Individuals of the three species were selected using a threshold of wet bodyweight with shell of $>0.5$ g, so as to prevent the analysis of excessively small individuals. Wet bodyweight with shell (g WW) was measured using a microbalance $(0.001 \mathrm{~g})$. For each station and species, samples $(n=3)$ made of one to four individuals were used for the digestion, reaching a total of nine samples per species. In total, 20 individuals for Cerastoderma spp., 19 individuals for $R$. decussatus and 25 for Polititapes spp. were processed across all stations. Bivalves were pooled maintaining a similar total biomass per sample and an appropriate volume to solution ratio to ensure a complete digestion of the organic matter and to avoid filter clogging during filtration. Individuals in each sample were rinsed with prefiltered ultrapure water (purified by an Elix (R) equipment and filtered through a GF/C Whatman 1.2 $\mathrm{mm}$ pore size) to remove potential external contaminants adhered to the shells. Shells were opened, and soft tissue was extracted and weighted ( $\mathrm{g} \mathrm{WW})$ using a microbalance $(0.001 \mathrm{~g})$, then rinsed again with pre-filtered ultrapure water. Soft wet-tissue biomasses ranged from 0.57 to $0.92 \mathrm{~g}$ WW in Cerastoderma spp., from 0.37 to $0.89 \mathrm{~g} \mathrm{WW}$ in $R$. decussatus and from 0.51 to $1.75 \mathrm{~g} \mathrm{WW}$ in Polititapes spp.

Soft tissue digestions and MP extractions were conducted using an adapted protocol from Dehaut et al. (2016). Each composite sample (i.e. replicate, one to four individuals) was placed in a $250 \mathrm{~mL}$ flask and $1.8 \mathrm{M} \mathrm{KOH}$ solution was added to digest the organic matter. A variable number of individuals is often used in digestions to ensure comparable biomass among replicates (e.g. Li et al. 
2015, 2016; Teng et al. 2019). The solution was stirred until complete digestion (i.e. 2 min) and placed in the oven at $60^{\circ} \mathrm{C}$ for $24 \mathrm{~h}$. After incubation, the whole solution was filtered through a Whatman GF/C glass-fibre filter (diameter $47 \mathrm{~mm}, 1.2 \mathrm{~mm}$ pore size), while still warm, by using a vacuum system. The resulting filters were placed in glass Petri dishes with lid, dried in the oven at $40^{\circ} \mathrm{C}$ for $24 \mathrm{~h}$, then examined for the presence of MPs under a stereomicroscope (ZEISS SteREO Discovery V8). Filters were kept sealed when not in use to avoid external contamination. Microplastic items were counted and measured (mm) using the software Image J (https:// imagej.nih.gov/ij/index.html; Schneider et al. 2012). Microplastics were classified according to their colours (blue, violet, yellow, red, green and colourless white) and shape (fibres, granules, foam, films and fragments; Gündoğdu and Çevik 2017). This was undertaken because high colour variability is a reliable proxy indicator of high variation in polymer composition and origin (Blettler et al. 2017). Further, abundant MP white colouration is indicative of pronounced degradation processes (e.g. UVintense solar radiation; Mbedzi et al. 2020).

Fibres were measured along their length, whereas foams and films were measured for their longest dimension. Every plastic particle was assigned to one of the following three distinct size classes of maximum length (Abidli et al. 2019): $>0.01-0.1 \mathrm{~mm},>0.1-1 \mathrm{~mm}$ and $>1-5 \mathrm{~mm}$. MP abundance was expressed as number of items per wet soft-tissue weight (items $\mathrm{g}^{-1} \mathrm{WW}$ ). Percentage of occurrence of MPs was obtained as the percentage of composite samples in which MPs were found.

The entire laboratory analysis for MP determination was conducted under a laminar flow cabinet. To limit post-sampling contamination, gloves and 100\% cotton laboratory coats were worn during the process. In addition, all equipment used was non-plastic (i.e. glass or metal), and was rinsed twice with pre-filtered ultrapure water between each sample extraction. To account for possible contamination, one procedural (blank) control (containing $\mathrm{KOH}$ solution only) was performed in parallel to each digestion batch, yielding an average procedural contamination of $1.8 \pm 1.3$ (mean \pm s.d., $n=9)$ MPs.

Data of MP abundance were $\log _{10}$-transformed to meet the normality and homoscedasticity assumptions (Shapiro-Wilk and Fligner-Killeen tests respectively). Differences among species in the abundance of MPs were tested with a one-way ANOVA, using the MP items per unit of biomass as the response variable and species (3 levels) as the fixed factor. Data analysis was performed using the R programming language R 3.6.1 (R Core Team 2019). 


\subsection{Polymer identification}

To obtain information on polymer composition and to validate MP identification, micro Raman spectroscopy was performed (JASCO NRS-4100, Laser Raman Spectrometer) on a subsample ( $n=$ 15) for each species (16.3\% representativeness on total number of MPs). The laser beam (532 or 785 $\mathrm{nm}$ ) was focused on the sample surface by a microscope objective. The availability of objectives with different magnification and numerical aperture ( 5 x /0.10 N.A., 20 x /0.40 N.A., and 100 x /0.90 N.A.) provided the possibility to perform both spatially averaged and high-resolution analyses. The laser power was adjusted according to the characteristics of the sample so as to obtain a suitably high Raman signal, yet preventing any damage. Spectra at different points of the sample surface were acquired to verify its homogeneity. To identify the polymer composition, the spectra were then compared with those of the most common polymers included in a home-made spectral database (Supplementary material Fig. S1, available at the journal's website). When identification through Raman analysis was ambiguous or not possible, usually owing to intense photoluminescence background, attenuated total reflection Fourier-transform infrared spectroscopy (ATR-FTIR) was used (JASCO FT/IR-4700). Several recent studies have highlighted the importance of Raman and FTIR spectroscopy to discriminate among natural items for synthetic polymers and, thus, to avoid overestimation of the MP concentration (e.g. Wesch et al. 2016).

\section{Results}

Microplastics were present in all samples and species (Table 1). Abundance of MPs found in the soft tissues of the bivalves was similar across species (one-way ANOVA, $F$-value $=0.459, P=0.637$ ), with average (mean \pm s.d., $n=9$ ) values of $18.4 \pm 21.9$ items $\mathrm{g}^{-1} \mathrm{WW}$ for $R$. decussatus, $11.9 \pm 5.5$ for Cerastoderma spp., and 10.4 \pm 10.4 MP items g ${ }^{-1}$ WW for Polititapes spp. (Table 1). Fibres were the most prevalent plastic category observed, accounting for $88 \%$ of total debris $(n=242)$ found in the three species. Foams and films formed the remaining $9.5 \%$ and $2.5 \%$ respectively (Fig. $2 a$ ). Neither fragments nor plastic pellets (nurdles) were detected. Among the three species, Cerastoderma spp. exhibited the highest concentration of fibres (94\%) and the lowest of foams (1\%), whereas Polititapes spp. had the highest number of foams (16\%) and the lowest of fibres (82\%). The lowest concentration of MP films was observed in R. decussatus (1\%; Fig. 2a).

Among all the fibres identified within the three species, blue (51.7\%), white $(21.9 \%)$ and violet $(14.9 \%)$ were the dominant colours, whereas the least represented colours were red (5.4\%; Fig. $2 b)$ 
and green $(0.4 \%)$, the latter with only one item detected across all samples. Size of MP items ranged from $0.037 \mathrm{~mm}$ to $4.7 \mathrm{~mm}$ in length. Size categories $>0.1-1 \mathrm{~mm}$ and $>1-5 \mathrm{~mm}$ were the most common, comprising $60.4 \%$ and $33.8 \%$ of the total MP abundance respectively (Fig. $2 c$ ).

Spectroscopy characterisation showed that $2 \%$ of putatively synthetic items were indeed of natural origin (e.g. keratin and cellulose) and these were discarded from the data. In $R$. decussatus and in Polititapes spp., polyethylene (PE) and polystyrene (PS) were present in equal proportions, followed by polypropylene (PP) and polyethylene terephthalate (PET). Microplastics found in Cerastoderma spp. were predominantly PE, whereas PS and PP were represented in similar proportions (Table 1). Overall, the most represented polymer was PE, accounting for $40 \%$ of total MPs found, followed by PS (31\%), PP (20\%) and PET (9\%; Fig. 2d).

Table 1. Frequency of occurrence (\%; i.e. the proportion of affected animals) of microplastics (MPs) in the samples of the three commercial bivalve species, their MP abundance as items per gram wet weight of animal tissue (mean \pm s.d., $n=9$ ), total number of MP items found in each species, and the percentage of occurrence for each polymer type of all MPs found in each species. PE, polyethylene; PS, polystyrene; PET, polyethylene terephthalate; PP, polypropylene.

\begin{tabular}{|l|l|l|l|l|l|l|l|}
\hline Species & $\begin{array}{l}\text { Frequency of } \\
\text { occurrence (\%) }\end{array}$ & $\begin{array}{l}\text { MP abundance } \\
\left(\text { items } \mathrm{g}^{-1} \mathrm{WW}\right)\end{array}$ & $\begin{array}{l}\text { Total MP } \\
\text { items }\end{array}$ & $\begin{array}{l}\text { PE } \\
(\%)\end{array}$ & $\begin{array}{l}\text { PS } \\
(\%)\end{array}$ & $\begin{array}{l}\text { PET } \\
(\%)\end{array}$ & $\begin{array}{l}\text { PP } \\
(\%)\end{array}$ \\
\hline $\begin{array}{l}\text { Ruditapes } \\
\text { decussatus }\end{array}$ & 100 & $18.4 \pm 21.9$ & 95 & 33.3 & 33.3 & 13.3 & 20 \\
\hline $\begin{array}{l}\text { Cerastoderma } \\
\text { spp. }\end{array}$ & 100 & $11.9 \pm 5.5$ & 80 & 46.7 & 20 & 6.7 & 26.7 \\
\hline Polititapes spp. & 100 & & & & & & \\
\hline
\end{tabular}




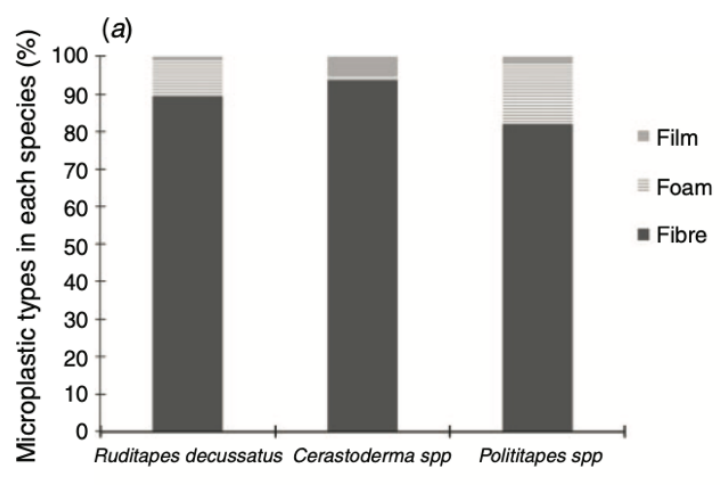

(c)

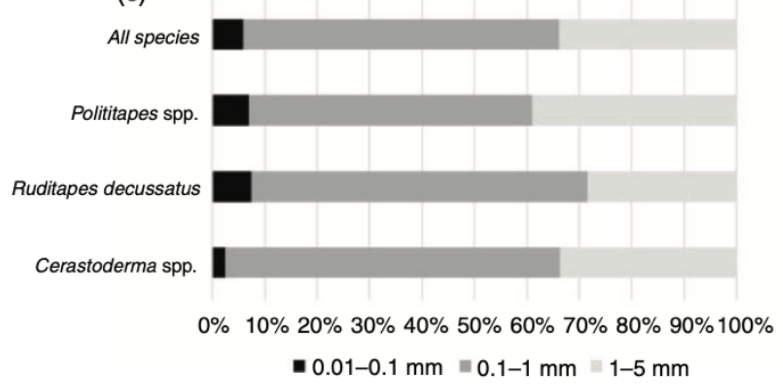

(b)

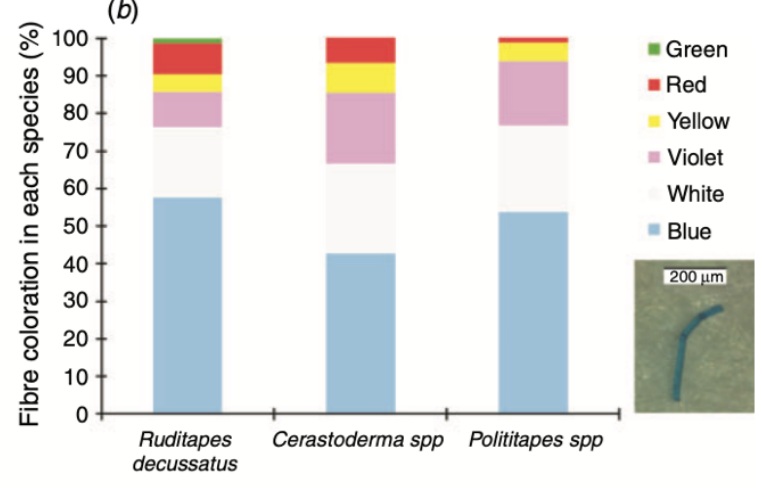

(d)

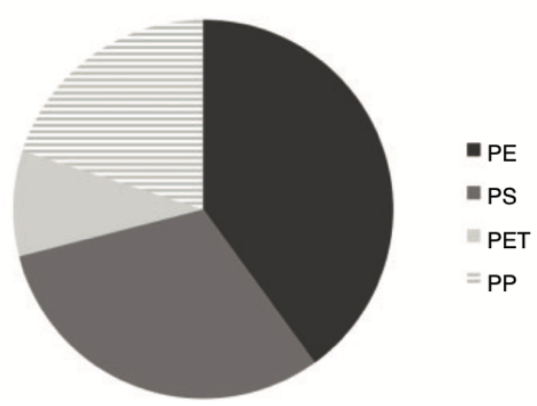

Fig. 2. (a) Percentage of occurrence of microplastics (MPs) by shape category in the three bivalve species (Ruditapes decussatus, Polititapes spp., Cerastoderma spp.); (b) percentage of occurrence of fibres by colour category and species; $(c)$ percentage of occurrence of MP size classes per species and in total; and $(d)$ percentage of occurrence of MPs by polymer category. PE, polyethylene; PS, polystyrene; PET, polyethylene terephthalate; and PP, polypropylene.

\section{Discussion}

Plastic pollution has now become a global concern and plastic litter entering the ocean threatens numerous organisms (Wilcox et al. 2016). In particular, filter feeders because they filter a large volume of seawater, are among the most severely affected organisms by microplastics (Gonçalves et al. 2019). For example, literature increasingly shows that MPs are ingested by filter-feeding organisms, such as sea cucumbers, lungworms and bivalves (Kinjo et al. 2019). Critically, bivalves, being a major food source for various predators, often act as vectors of MP to higher trophic levels in ecosystems (Farrell and Nelson 2013), including humans (Li et al. 2015; Smith et al. 2018). This study has provided preliminary quantitative and qualitative baseline data on MP content in the soft tissues of three commercially important bivalves collected intertidally in the Ria Formosa lagoon, southern Portugal. Overall, we found that the three species assessed (R. decussatus, Polititapes spp. and Cerastoderma spp.) were contaminated with a similar number of MPs, ranging from $10.4 \pm 10.4$ 
to $18.4 \pm 21.9$ items $\mathrm{g}^{-1} \mathrm{WW}$, the majority of the particles being fibres $(88 \%)$, blue in colour (52\%), in the range of $0.1-1 \mathrm{~mm}$, and made of polyethylene (PE, 40\%) and polystyrene (PS, 31\%).

The present work has highlighted higher concentrations of MPs in bivalves than have studies conducted in other systems (Table 2). For example, MP concentrations here observed in $R$. decussatus are an order of magnitude higher than those reported by Abidli et al. $\left(2019 ; 1.4\right.$ items $\left.\mathrm{g}^{-1} \mathrm{WW}\right)$. Relatively low MP concentrations were also reported for the Manila clams, Ruditapes philippinarum, from different regions; Davidson and Dudas (2016) detected an average of $0.9 \pm 0.9$ items $\mathrm{g}^{-1} \mathrm{WW}$ in Baynes Sound (British Columbia), Li et al. (2015) reported 3 MP items $\mathrm{g}^{-1} \mathrm{WW}$ in China, and Cho et al. (2019) observed an average of $0.34 \pm 0.31$ items $\mathrm{g}^{-1} \mathrm{WW}$ in South Korea. Similarly, the MP concentrations that we observed for Cerastoderma spp. (11.9 \pm 5.5 MPs items $\left.\mathrm{g}^{-1} \mathrm{WW}\right)$ are, on average, 94\% higher than those in the common cockle (Cerastoderma edule) collected in France (Hermabessiere et al. 2019).

Table 2. Comparison among microplastic abundances (items $\mathrm{g}^{-1} \mathrm{WW}$ of animal tissue; mean \pm s.d.) in different bivalve species collected from different regions worldwide. n.a., Not available.

\begin{tabular}{|l|l|l|l|}
\hline Species & Location & $\begin{array}{l}\text { MP items } \\
\left(\mathbf{g}^{-1} \mathbf{W W}\right)\end{array}$ & Reference \\
\hline Ruditapes decussatus & Lagoon of Bizerte (northern Tunisia) & $1.4 \pm$ n.a. & Abidli et al. (2019) \\
\hline Cerastoderma edule & Channel coastlines (France) & $0.74 \pm 0.35$ & Hermabessiere et al. (2019) \\
\hline Mytilus edulis & Channel coastlines (France) & $0.25 \pm 0.16$ & Hermabessiere et al. (2019) \\
\hline M. edulis & French Brittany & $0.36 \pm 0.07$ & Van Cauwenberghe and Janssen (2014) \\
\hline M. galloprovincialis & China & $\sim 2 \pm$ n.a. & Li et al. (2015) \\
\hline Ruditapes philippinarum & China & $\sim 3 \pm$ n.a. & Li et al. (2015) \\
\hline R. philippinarum & Baynes Sound (British Columbia) & $0.9 \pm 0.9$ & Davidson and Dudas (2016) \\
\hline R. philippinarum & South Korea & $0.34 \pm 0.31$ & Cho et al. (2019) \\
\hline
\end{tabular}

Microplastic occurrence has been documented in a variety of other bivalve species. For instance, in mussels, the average MP concentrations range between $0.25 \pm 0.16$ items $\mathrm{g}^{-1} \mathrm{WW}$ along the Channel coastline (Hermabessiere et al. 2019) and 0.36 \pm 0.07 items $\mathrm{g}^{-1} \mathrm{WW}$ in French Brittany (Van Cauwenberghe and Janssen 2014) and $2 \pm 1$ MP items $\mathrm{g}^{-1} \mathrm{WW}$ in China (Li et al. 2015). Despite our results highlighting high levels of MPs in the Ria Formosa bivalves, a recent work investigating MP pollution in the sediment of vegetated and unvegetated habitats within the lagoon showed low MP densities, 
namely, one order of magnitude lower than densities reported in other studies conducted in similar systems (Cozzolino et al. 2020). Such apparent discrepancies among MP densities in bivalves and in sediment could be the result of the high accumulation efficiency and retention of bivalves.

In our study, despite lack of significant differences among species, the higher levels (on average 35\% and $43.5 \%$ more than in Cerastoderma spp. and Polititapes spp. respectively) of MP contamination found in $R$. decussatus is in agreement with previous works reporting this species as the most contaminated of the six molluscs harvested from the lagoon of Bizerte, Tunisia (Abidli et al. 2019). It is difficult to pinpoint the drivers of the higher ingestion rates in this species; however, experiments conducted with $R$. decussatus from the Ria Formosa have shown that this species is able to maintain a higher filtration rate than coexisting suspension feeders across a wide range of current velocities (Sobral and Widdows 2000). Laboratory studies taking multiple physiological parameters into consideration will be key to address interspecific variations in MP ingestion.

In addition to organisms' features, there is an increasing literature on the determinant role of habitats in affecting MPs ingested by shellfish (Murphy et al. 2017). For example, significant variation of MP features exists between shellfish growing in water and those growing in sediment (Ding et al. 2020). The bivalve species assessed here grow in the sediment, yet in contrasting types. Whereas individuals of Cerastoderma spp. and $R$. decussatus were collected from sandbanks, those of Polititapes spp. were sampled from seagrass meadows. Recent evidence on plastic accumulation in the sediment of unvegetated and vegetated habitats (including the seagrass $Z$. noltei) in the same geographical area as this study showed that MPs occur in similar concentrations (Cozzolino et al. 2020). However, seagrasses have the potential of filtering fibres out of the water column by adhesion to their leaves (Goss et al. 2018; Cozzolino et al. 2020; Seng et al. 2020). This could have an effect on the MP exposure to the organisms living within the sediment of the seagrass meadows, in comparison to those inhabiting unvegetated areas. Further research and direct testing would be needed to understand the effects of habitat type on the MP exposure and accumulation of bivalve species and other filterfeeders.

In our study, fibres were the category most represented, which is in agreement with previous studies on $R$. decussatus (91\%) and R. philippinarum (90\%; Abidli et al. 2019; Davidson and Dudas 2016) and on the cockle Cerastoderma edule (Hermabessiere et al. 2019). Other studies have described similar high fibre concentrations in several bivalves, in particular Chlamys ferreris and Mytilus 
galloprovincialis of the northern Ionian Sea (84\%; Digka et al. 2018) and in Saccostrea cucullata of China (69\%; Li et al. 2018). Regarding the MP size categories, the outcomes of our investigation are consistent with previous studies assessing MP concentrations in commercial bivalves from other regions. In Abidli et al. (2019) and Digka et al. (2018), the most represented microplastic size classes were $0.1-1 \mathrm{~mm}$ and $0.1-0.5 \mathrm{~mm}$ respectively. Critically, evidence shows that each size and colour of MPs has a different detection probability; items with inconspicuous colouring (e.g. white) and size (<300 mm) may be largely underestimated (Nel et al. 2019).

The overall high concentrations of fibres observed in our study are likely to be linked to anthropogenic factors such as the wastewater and domestic discharges in the lagoon. Despite removal efficiency of wastewater treatment facilities can be very high (95-99\%), municipal wastewater effluents remain a conspicuous pathway for MPs to reach aquatic systems (Murphy et al. 2016, and references therein). Four WWTPs are located in the western side of the Ria Formosa lagoon (Fig. 1), the effluents of which may represent a significant risk of water contamination depending on treatment efficiency, volume of effluent and presence of leakages in the network (Kay et al. 2008; Pedro et al. 2008; Pommepuy et al. 2004; Riou et al. 2007). According to the models of water and particle circulation of Ria Formosa (Fabia oetal.2016) and in terms of proximity to the three sampled stations, the most relevant inputs of discharge are the WWTPs of Olhão-Nascente (PE 32.216; Águas do Algarve) and Faro-Nascente (PE 87.320; European Commission Urban Waste Water, https://uwwtd.eu/Portugal/agglomeration/ptag1003/2016). Importantly, the particles released from Olhão-Nascente show a mean residence time within the lagoon system of $\sim 7$ days (being concentrated between Culatra and Fuseta islands), before being washed out through the Armona inlet (Fabião et al. 2016). The particles discharged from Faro-Nascente remain longer in the system ( $\sim 18$ days) because of a complex interconnectivity among channels in the western area of the lagoon (Fabião et al. 2016). Such high retention times can result in an extended particle contamination exposure for the ecosystems in the Ria Formosa.

The island of Culatra, where this study took place, represents an important fishing ground for the local community and recent evidence shows that fishing is a conspicuous source of plastic pollution at this site (Velez et al. 2020). Fishing gears that include nets, ropes and traps, mostly made of nylon, polyethylene (PE) and polyester (Kanehiro 2004), are lost or discarded during fishing activities and, after long-term exposition to the physical-chemical pressures of the aquatic environment, can result in fibrous pollution (Browne et al. 2011). In agreement with previous works on commercial bivalves 
(e.g. Li et al. 2015; Cho et al. 2019), PE is the most abundant polymer observed in this study. Although no fragments were identified in the study, their occurrence has been reported in bivalves, with proportions ranging from 5-6\% (Davidson and Dudas 2016; Abidli et al. 2019) to 15-20\% (Digka et al. 2018; Li et al. 2018).

\section{Conclusions}

This study has provided the first evidence of MP contamination in bivalves living in Ria Formosa lagoon (Portugal), thus setting a baseline to evaluate future changes. Overall, it highlighted high concentrations of microplastics in cockles (Cerastoderma spp.) and clams (Ruditapes decussatus and Polititapes spp.) from this lagoon. Further research taking into account species ecological and physiological traits contributing to MP ingestion is needed to provide a more complete understanding of species' vulnerability to MP pollution in the lagoon and to underline potential differences among species. In addition, as these bivalves are commonly consumed as seafood, the potential for bioaccumulation and biomagnification of chemicals should be further addressed to infer risks for human health.

\section{Conflicts of interests}

The authors declare that they have no conflicts of interest.

\section{Declaration of funding}

This research received Portuguese national funds from FCT - Foundation for Science and Technology, through projects PTDC/MAR-EST/3223/2014, IF/01413/2014/CP1217/CT0004, UIDB/04326/2020, SFRH/BPD/119344/2016, and it was further supported by the National Research Foundation of South Africa (Grant number 64801).

\section{Acknowledgements}

Authors are thankful to A. Silva, C. Freitas, R. Texeira, A. Marçaal and N. Velez for the assistance in the field and laboratory.

\section{Appendix A Supplementary data}

Supplementary data to this article can be found online at:

https://www.publish.csiro.au/mf/acc/MF20202/MF20202_AC.pdf 


\section{References}

\section{References}

Abidli, S., Lahbib, Y., and El Menif, N. T. (2019). Microplastics in commercial molluscs from the lagoon of Bizerte (northern Tunisia). Marine Pollution Bulletin 142, 243-252. doi:10.1016/J.MARPOLBUL. 2019.03.048

Almeida, C., and Soares, F. (2012). Microbiological monitoring of bivalves from the Ria Formosa lagoon (south coast of Portugal): a 20 years of sanitary survey. Marine Pollution Bulletin 64(2), 252-262. doi:10.1016/ J.MARPOLBUL.2011.11.025

Alomar, C., Estarellas, F., and Deudero, S. (2016). Microplastics in the Mediterranean Sea: deposition in coastal shallow sediments, spatial variation and preferential grain size. Marine Environmental Research 115, 1-10.

Aníbal, J., Gomes, A., Mendes, I., and Moura, D. (2019). 'RiaFormosa: challenges of a coastal lagoon in a changing environment.' 1st edn. (University of Algarve: Faro, Portugal) ISBN 978-989-8859-72-3

Avio, C. G., Gorbi, S., Milan, M., Benedetti, M., Fattorini, D., d'Errico, G., Pauletto, M., Bargelloni, L., and Regoli, F. (2015). Pollutants bioavailability and toxicological risk from microplastics to marine mussels. Environmental Pollution 198, 211-222. doi:10.1016/J.ENVPOL.2014.12.021

Barnes, D. K. A., Galgani, F., Thompson, R. C., and Barlaz, M. (2009). Accumulation and fragmentation of plastic debris in global environments. Philosophical Transaction of the Royal Society of London. B Biological Sciences 364, 1985-1998.

Bebianno, M. J. (1995). Effects of pollutants in the Ria Formosa lagoon, Portugal. The Science of the Total Environment 171(1-3), 107-115. doi:10.1016/0048-9697(95)04672-9

Bernardino, F. N. V. (2000). Review of aquaculture development in Portugal. Journal of Applied IchthyologyZeitschrift Fur Angewandte Ichthyologie 16(4-5), 196-199. doi:10.1046/J.1439-0426.2000.00262.X

Blettler, M. C., Ulla, M. A., Rabuffetti, A. P., and Garello, N. (2017). Plastic pollution in freshwater ecosystems: macro-, meso-, and microplastic debris in a floodplain lake. Environmental Monitoring and Assessment 189(11), 581. doi:10.1007/S10661-017-6305-8

Browne, M. A., Dissanayake, A., Galloway, T. S., Lowe, D. M., and Thompson, R. C. (2008). Ingested microscopic plastic translocates to the circulatory system of the mussel, Mytilus edulis (L.). Environmental Science \& Technology 42(13), 5026-5031. doi:10.1021/ES800249A

Browne, M. A., Crump, P., Niven, S. J., Teuten, E., Tonkin, A., Galloway, T., and Thompson, R. (2011). Accumulation of microplastic on shorelines worldwide: sources and sinks. Environmental Science \& Technology 45(21), 9175-9179. doi:10.1021/ES201811S

Catarino, A. I., Macchia, V., Sanderson, W. G., Thompson, R. C., and Henry, T. B. (2018). Low levels of microplastics (MP) in wild mussels indicate that MP ingestion by humans is minimal compared to 
exposure via household fibres fallout during a meal. Environmental Pollution 237, 675-684. doi:10.1016/J.ENVPOL.2018.02.069

Cho, Y., Shim, W. J., Jang, M., Han, G. M., and Hong, S. H. (2019). Abundance and characteristics of microplastics in market bivalves from South Korea. Environmental Pollution 245, 1107-1116. doi:10.1016/ J.ENVPOL.2018.11.091

Cozzolino, L., Nicastro, K. R., Zardi, G. I., and de los Santos, C. B. (2020). Species-specific plastic accumulation in the sediment and canopy of coastal vegetated habitats. The Science of the Total Environment 723, 138018. doi:10.1016/J.SCITOTENV.2020.138018

Cunha, A. H., Assis, J., and Serrão, E. A. (2009). Estimation of available seagrass meadow area in Portugal for transplanting purposes. Journal of Coastal Research 56, 1100-1104.

Dame, R. F. (2016). 'Ecology of Marine Bivalves: An Ecosystem Approach.' (CRC Press.)

Davidson, K., and Dudas, S. E. (2016). Microplastic ingestion by wild and cultured Manila clams (Venerupis philippinarum) from Baynes Sound, British Columbia. Archives of Environmental Contamination and Toxicology 71(2), 147-156. doi:10.1007/S00244-016-0286-4

De Witte, B., Devriese, L., Bekaert, K., Hoffman, S., Vandermeersch, G., Cooreman, K., and Robbens, J. (2014). Quality assessment of the blue mussel (Mytilus edulis): comparison between commercial and wild types. Marine Pollution Bulletin 85(1), 146-155. doi:10.1016/J.MAR POLBUL.2014.06.006

Dehaut, A., Cassone, A. L., Frère, L., Hermabessiere, L., Himber, C., Rinnert, E., and Duflos, G. (2016). Microplastics in seafood: benchmark protocol for their extraction and characterization. Environmental Pollution 215, 223-233. doi:10.1016/J.ENVPOL.2016.05.018

Digka, N., Tsangaris, C., Torre, M., Anastasopoulou, A., and Zeri, C. (2018). Microplastics in mussels and fish from the northern Ionian Sea. Marine Pollution Bulletin 135, 30-40. doi:10.1016/J.MARPOLBUL.2018.06.063

Ding, J., Li, J., Sun, C., Jiang, F., He, C., Zhang, M., Ju, P., and Ding, X. N. (2020). An examination of the occurrence and potential risks of micro- plastics across various shellfish. The Science of the Total Environment 739, 139887. doi:10.1016/J.SCITOTENV.2020.139887

Fabião, J. P. F., Rodrigues, M. F. G., Fortunato, A. B., de Brito Jacob, J. M. Q., and Cravo, A. M. F. (2016). Water exchanges between a multi-inlet lagoon and the ocean: the role of forcing mechanisms. Ocean Dynamics 66(2), 173-194. doi:10.1007/S10236-015-0918-7

Farrell, P., and Nelson, K. (2013). Trophic level transfer of microplastic: Mytilus edulis (L.) to Carcinus maenas (L.). Environmental Pollution 177, 1-3. doi:10.1016/J.ENVPOL.2013.01.046

Gonçalves, C., Martins, M., Sobral, P., Costa, P. M., and Costa, M. H. (2019). An assessment of the ability to ingest and excrete microplastics by filter-feeders: a case study with the Mediterranean mussel. Environmental Pollution 245, 600-606. doi:10.1016/J.ENVPOL.2018.11.038 
Goss, H., Jaskiel, J., and Rotjan, R. (2018). Thalassia testudinum as a potential vector for incorporating microplastics into benthic marine food webs. Marine Pollution Bulletin 135, 1085-1089. doi:10.1016/J.MAR POLBUL.2018.08.024

Guimarães, M. H. M., Cunha, A. H., Nzinga, R. L., and Marques, J. F. (2012). The distribution of seagrass (Zostera noltii) in the Ria Formosa lagoon system and the implications of clam farming on its conservation. Journal for Nature Conservation 20(1), 30-40. doi:10.1016/J.JNC.2011.07.005

Gündoğdu, S., and Çevik, C. (2017). Micro- and mesoplastics in northeast Levantine coast of Turkey: the preliminary results from surface samples. Marine Pollution Bulletin 118(1-2), 341-347. doi:10.1016/J.MARPOL BUL.2017.03.002

Hermabessiere, L., Paul-Pont, I., Cassone, A. L., Himber, C., Receveur, J., Jezequel, R., and Huvet, A. (2019). Microplastic contamination and pollutant levels in mussels and cockles collected along the channel coasts. Environmental Pollution 250, 807-819. doi:10.1016/J. ENVPOL.2019.04.051

Kanehiro, H. (2004). Disposal and recycling of fisheries plastic wastes: fishing net and expanded polystyrene. In 'Developments in Food Science'. Vol. 42. (Ed. M. Sakaguchi.) pp. 253-261. (Elsevier.)

Karlsson, T. M., Vethaak, A. D., Almroth, B. C., Ariese, F., van Velzen, M., Hassellov, M., and Leslie, H. A. (2017). Screening for microplastics in sediment, water, marine invertebrates and fish: method development and microplastic accumulation. Marine Pollution Bulletin 122(1-2), 403-408. doi:10.1016/J.MARPOLBUL.2017.06.081

Kay, D., Kershaw, S., Lee, R., Wyer, M. D., Watkins, J., and Francis, C. (2008). Results of field investigations into the impact of intermittent sewage discharges on the microbiological quality of wild mussels (Mytilus edulis) in a tidal estuary. Water Research 42(12), 3033-3046. doi:10.1016/J.WATRES.2008.03.020

Kinjo, A., Mizukawa, K., Takada, H., and Inoue, K. (2019). Size-dependent elimination of ingested microplastics in the Mediterranean mussel Mytilus galloprovincialis. Marine Pollution Bulletin 149, 110512. doi:10.1016/J.MARPOLBUL.2019.110512

Kolandhasamy, P., Su, L., Li, J., Qu, X., Jabeen, K., and Shi, H. (2018). Adherence of microplastics to soft tissue of mussels: a novel way to uptake microplastics beyond ingestion. The Science of the Total Environment 610-611, 635-640. doi:10.1016/J.SCITOTENV.2017.08.053

Li, J., Yang, D., Li, L., Jabeen, K., and Shi, H. (2015). Microplastics in commercial bivalves from China. Environmental Pollution 207, 190-195. doi:10.1016/J.ENVPOL.2015.09.018

Li, J., Qu, X., Su, L., Zhang, W., Yang, D., Kolandhasamy, P., Li, D., and Shi, H. (2016). Microplastics in mussels along the coastal waters of China. Environmental Pollution 214, 177-184. doi:10.1016/J.ENVPOL. 2016.04.012

Li, H. X., Ma, L. S., Lin, L., Ni, Z. X., Xu, X. R., Shi, H. H., Tan, Y., Zheng, G., and Rittschof, D. (2018). Microplastics in oysters Saccostrea cucullata along the pearl river estuary, China. Environmental Pollution 236, 619-625. doi:10.1016/J.ENVPOL.2018.01.083 
Mbedzi, R., Cuthbert, R. N., Wasserman, R. J., Murungweni, F. M., and Dalu, T. (2020). Spatiotemporal variation in microplastic contamination along a subtropical reservoir shoreline. Environmental Science and Pollution Research International 27, 1-8.

Murphy, C. L. (2018). A comparison of microplastics in farmed and wild shellfish near Vancouver Island and potential implications for contaminant transfer to humans. M.Sc. thesis, Royal Roads University Victoria, British Columbia, Canada.

Murphy, F., Ewins, C., Carbonnier, F., and Quinn, B. (2016). Wastewater treatment works (WwTW) as a source of microplastics in the aquatic environment. Environmental Science \& Technology 50(11), 5800-5808. doi:10.1021/ACS.EST.5B05416

Murphy, F., Russell, M., Ewins, C., and Quinn, B. (2017). The uptake of macroplastic \& microplastic by demersal \& pelagic fish in the Northeast Atlantic around Scotland. Marine Pollution Bulletin 122(12), 353-359. doi:10.1016/J.MARPOLBUL.2017.06.073

Nel, H. A., Dalu, T., Wasserman, R. J., and Hean, J. W. (2019). Colour and size influences plastic microbead underestimation, regardless of sediment grain size. The Science of the Total Environment 655, 567570. doi:10.1016/J.SCITOTENV.2018.11.261

Oliveira, J., Castilho, F., Cunha, A., and Pereira, M. J. (2013). Bivalve harvesting and production in Portugal: an overview. Journal of Shellfish Research 32(3), 911-925. doi:10.2983/035.032.0334

Pedro, S., Castilho, M. F., and Silva, H. A. (2008). Principais perigos associados aos bivalves; contaminantes microbiológicos; generalidade. In 'Produção, Salubridade e Comercializaçãpo de Moluscos Bivalves em Portugal'. (Eds H. A. Silva and I. Baptista.) pp. 74-75. (Publicações avulsas do IPIMAR: Lisboa, Portugal.)

Pommepuy, M., Dumas, F., Caprais, M. P., Camus, P., Le Mennec, C., Parnaudeau, S., et al. (2004). Sewage impact on shellfish microbial contamination. Water Science and Technology 50(1), 117-124. doi:10.2166/WST.2004.0035

R Core Team (2019). R: a language and environment for statistical computing. R Foundation for Statistical Computing, Vienna, Austria. Available at https://r-project.org/.

Ribeiro, J., Bentes, L., Coelho, R., Gonc alves, J. M., Lino, P. G., Monteiro, P., and Erzini, K. (2006). Seasonal, tidal and diurnal changes in fish assemblages in the Ria Formosa lagoon (Portugal). Estuarine, Coastal and Shelf Science 67(3), 461-474. doi:10.1016/J.ECSS.2005.11.036

Ribeiro, F., Garcia, A. R., Pereira, B. P., Fonseca, M., Mestre, N. C., Fonseca, T. G., Fonseca, L. M., and Ilharco, M. J. B. (2017). Microplastics effects in Scrobicularia plana. Marine Pollution Bulletin 122(1-2), 379-391. doi:10.1016/J.MARPOLBUL.2017.06.078

Riou, P., Le Saux, J. C., Dumas, F., Caprais, M. P., Le Guyader, S. F., and Pommepuy, M. (2007). Microbial impact of small tributaries on water and shellfish quality in shallow coastal areas. Water Research 41(12), 2774-2786. doi:10.1016/J.WATRES.2007.03.003 
Rochman, C. M., Tahir, A., Williams, S. L., Baxa, D. V., Lam, R., Miller, J. T., The, F., Werorilangi, S., and The, S. J. (2015). Anthropogenic debris in seafood: plastic debris and fibers from textiles in fish and bivalves sold for human consumption. Scientific Reports 5, 14340. doi:10.1038/SREP14340

Schneider, C. A., Rasband, W. S., and Eliceiri, K. W. (2012). NIH Image to ImageJ: 25 years of image analysis. Nature Methods 9(7), 671. doi:10.1038/NMETH.2089

Seng, N., Lai, S., Fong, J., Saleh, M. F., Cheng, C., Cheok, Z. Y., and Todd, P. A. (2020). Early evidence of microplastics on seagrass and macroalgae. Marine and Freshwater Research 71(8), 922-928. doi:10.1071/ MF19177

Smith, M., Love, D. C., Rochman, C. M., and Neff, R. A. (2018). Microplastics in seafood and the implications for human health. Current Environmental Health Reports 5(3), 375-386. doi:10.1007/S40572- 0180206-Z

Sobral, P., and Widdows, J. (2000). Effects of increasing current velocity, turbidity and particle-size selection on the feeding activity and scope for growth of Ruditapes decussatus from Ria Formosa, southern Portugal. Journal of Experimental Marine Biology and Ecology 245(1), 111-125. doi:10.1016/S00220981(99)00154-9

Sussarellu, R., Suquet, M., Thomas, Y., Lambert, C., Fabioux, C., Pernet, M. E. J., et al. (2016). Oyster reproduction is affected by exposure to polystyrene microplastics. Proceedings of the National Academy of Sciences of the United States of America 113(9), 2430-2435. doi:10.1073/PNAS.1519019113

Tallec, K., Huvet, A., Di Poi, C., González-Fernández, C., Lambert, C., Petton, B., et al. (2018). Nanoplastics impaired oyster free living stages, gametes and embryos. Environmental Pollution 242, 1226-1235. doi:10.1016/J.ENVPOL.2018.08.020

Teng, J., Wang, Q., Ran, W., Wu, D., Liu, Y., Sun, S., Cao, R., and Zhao, J. (2019). Microplastic in cultured oysters from different coastal areas of China. The Science of the Total Environment 653, 1282-1292. doi:10.1016/J.SCITOTENV.2018.11.057

Van Cauwenberghe, L., and Janssen, C. R. (2014). Microplastics in bivalves cultured for human consumption. Environmental Pollution 193, 65-70. doi:10.1016/J.ENVPOL.2014.06.010

Velez, N., Nicastro, K. R., McQuaid, C. D., and Zardi, G. I. (2020). Small scale habitat effects on anthropogenic litter material and sources in a coastal lagoon system. Marine Pollution Bulletin 160, 111689.

Veloso, N., Cruz, P., Carvalho, H., and da Silva, M. M. (2015). Monitoring urban storm water: facing climate changes in a Mediterranean coastal city. WIT Transactions on Ecology and the Environment 194, 93103. doi:10.2495/SC150091

von Moos, N., Burkhardt-Holm, P., and Koehler, A. (2012). Uptake and effects of microplastics on cells and tissues of the blue mussel Mytilus edulis L. after experimental exposure. Environmental Science \& Technology 46, 11327-11335. doi:10.1021/ES302332W 
Ward, J. E., Rosa, M., and Shumway, S. E. (2019a). Capture, ingestion, and egestion of microplastics by suspension-feeding bivalves: a 40-year history. Anthropocene Coasts 2(1), 39-49. doi:10.1139/ANC2018-0027

Ward, J. E., Zhao, S., Holohan, B. A., Mladinich, K. M., Griffin, T. W., Wozniak, J., and Shumway, S. E. (2019b). Selective ingestion and egestion of plastic particles by the blue mussel (Mytilus edulis) and eastern oyster (Crassostrea virginica): implications for using bivalves as bioindicators of microplastic pollution. Environmental Science \& Technology 53(15), 8776-8784. doi:10.1021/ACS.EST.9B02073

Wesch, C., Bredimus, K., Paulus, M., and Klein, R. (2016). Towards the suitable monitoring of ingestion of microplastics by marine biota: a review. Environmental Pollution 218, 1200-1208. doi:10.1016/J. ENVPOL.2016.08.076

Wilcox, C., Mallos, N. J., Leonard, G. H., Rodriguez, A., and Hardesty, B. D. (2016). Using expert elicitation to estimate the impacts of plastic pollution on marine wildlife. Marine Policy 65, 107-114. doi:10.1016/ J.MARPOL.2015.10.014 